\title{
First Footprints
}

\section{Erin Buechele}

University of Technology Sydney, Faculty of Arts and Social Sciences, PO Box 123, Ultimo NSW 2007, Australia. ebuechele@umass.edu

History should be written to inform the present and honour the past. In order to successfully meet this criteria history needs to be retold, above all else, truthfully. This truthfulness requires a brazen acknowledgement of past actions and events no matter how they reflect on the nation. In the case of Australian history, and any other colonizing nation, that truth contains harmful realities of oppression. Because of this, history is often reconstructed in a form that is easier to swallow or in a way that benefits those leading the nation. Because records are largely made by white people, they have far too often become subjective retellings of history used to justify actions made by white administrators and political leaders of the past and present.

Aboriginal history is not only a distinct and immensely rich field, but it also flows beautifully into a multitude of disciplines and intellectual currents. The interweaving of Aboriginal history within disciplines like anthropology, sociology, and science are clearly demonstrated in the documentary First Footprints (2013) which explores historic artefacts through the eyes of both Margaret, whose ancestors once populated the very land being researched by archaeologist, Dr Bruno David. This co-exploration of a shared history is just one example of a truthful recounting of the past. Investigations like First Footprints show how we can understand Aboriginal historiography in relation to many academic fields. We can do this by studying and teaching not only what has been done to oppress these communities but lifting up the ways in which they survived and thrived before colonization and recognizing the strength and resilience of the Aboriginal Australian experience today.

When asked, "Is Aboriginal history Australian history?" I would argue not only is Aboriginal history definitively Australian history but moreover, Australian history is incomplete and inaccurate without the incorporation of the Aboriginal Australian experience. Unfortunately, as W.E.H. Stanner tirelessly points out in his text 'The Great Australian Silence', the field of Australian academia falls significantly short when telling this history (1969). Stanner references a long list of academic texts which claim to dictate the history of this country all while failing to even touch on Aboriginal experience. Henry Reynolds, author of "'The Other Side of the Frontier' (1981) demonstrates how academic text can incorporate the voices of

\section{(c) (i)}


Aboriginal Australians. Reynolds uses oral histories to ensure both sides of Australian history are being told. Digging into the deep histories of ingenious Australia obviously poses significant challenges. However, through watching First Footprints and reading the works of both Stanner and Reynolds, one thing is particularly clear: if we intend to tell the story of Australia's past, white intellectuals cannot be the only people speaking. There is a deep and rich history in the oral stories of Aboriginal Australians, the question is, who is taking the time to listen?

\section{References}

First Footprints: Super Nomads, Documentary, ABC, 2012.

Reynolds, H., 1990, The other side of the frontier: Aboriginal resistance to the European invasion of Australia, Ringwood, Vic, Penguin, pp 5-29.

Stanner, W.E.H. 1969, 'The Great Australian Silence', The 1968 Boyer Lectures: After The Dreaming, ABC Enterprises, Sydney, pp. 18-29. 